\title{
ACRL at the Midwinter Meeting
}

\section{Actions of the ACRL Board of Directors}

D uring the 2000 ALA Midwinter Meeting in San Antonio, the ACRL Board of Directors met on January 16 and 18 and took the following actions

\section{ACRL governance}

Approved, upon recommendation from the Bylaws committee, revisions to the Bylaws of its English and Literature Section, Asian, African, and Middlle East Section, Community and Junior College Libraries Section, and Education and Behavioral Science Section.

Voted to approve ACRL Strategic Plan 2005 (see http:// www.ala.org/acrl/ stratpla.html).

\section{ACRL structure}

\section{Established the ACRL Committee on Eth-} ics and its charge to enhance awareness of the ethical context of service in an academic library; to educate academic librarians on how to address ethical issues effectively; to articulate core ethical principles that define the interpretation of ethical issues in the workplace; to clarify professional issues relating to ethics in a way that reflects many perspectives; to promote awareness of academic librarianship ethics on the part of the communities served; through its work to improve the quality of academic library service and of the atmosphere in which it takes place

\section{Finances}

Approved, upon recommendation from the Budget and Finance Committee, the following changes to the FY2000 Budget: added budgets for two preconferences-1) Licensing and 2) Legislative Leadership Training; allocated funds for three new programsCHEMA Joint Partnership and Effective Practices in Higher Education, Information Literacy Best Practices, and ACRL scholarships; and revised the revenues and expenses for the Ohio Immersion Program and the RBMS Preconference.

Approved a policy on Annual Conference Speaker honoria for section and committee programs that established a $\$ 500$ ceiling.

Approved allocations to support scholarships for two ACRL programs: 1) Institute for Information Literacy Immersion Program 2000 at the University of Washington$\$ 10,000$; and 2) Legislative Leadership training preconference before the ALA 2000 Annual Conference in Chicago, $\$ 12,600$ to provide $\$ 300$ to each of the ACRL Chapters for one of its members to participate.

\section{Government relations}

Endorsed, upon recommendation from the Government Relations Committee, a resolution supporting enactment of DH.R.1858, 
Consumers and Investors Access to Information Act of 1999.

\section{Endorsed, upon recommendation from} the Government Relations Committee, ALA's position to oppose the Uniform Computer Information Transaction Act (UCITA), which proposes to transfer intellectual property from copyright law to contract law without taking into consideration the intermediary role of libraries.

\section{Approved two resolutions of apprecia-} tion from the Government Relations Committee: 1) Deputy Secretary of Agriculture Richard Romenger for his strong support of the National Agriculture Library and other library issues, and 2) Michael Godow upon his resignation for his work for ACRL over the past three years.

\section{Endorsed, upon} request from ALA Committee on Legislation, a "Resolution on No-fee Permanent Public Access to Scientific and Technical Information (STI)."

\section{Partnerships}

Approved ACRL's

participation in the

Council for Higher Education Management Associations (CHEMA) Effective Practices in Higher Education Web project

\section{Professional development}

Approved two preconferences to be held before the 2001 ALA Annual Conference in San Francisco: 1) The Rare Books and Manuscripts Section will offer its $42^{\text {nd }}$ preconference, June $12-15,2001$; 2) the Instruction Section will offer its preconference on June 15, 2001, tentatively titled "Information Literacy Assessment in Higher Education."

\section{Voted to support, the ALA Web-CE 2005} proposal excluding the suggested divisional financial contribution until an acceptable business plan has been presented to the ACRL Board.

\section{Publications}

Approved, upon recommendation from the Publications Committee, a Royalties Policy for authors, editors, and compilers of ACRL non-serial publications.

\section{Recognition}

Approved a resolution of appreciation to Richard Dougherty for distinguished services to ACRL, ALA, and the profession and asked that the ALA Council endorse the resolution at its 2000 Annual Conference in Chicago.

\section{Standards}

Approved, upon recommendation from the Standards and Accreditation Committee, the revised "Standards for College Libraries," the first among academic libraries to be written using both input and output measures (see page 175).
Section officers Carol Ritzen Kem and Mary G. Wrighten attended the ACRL Leadership Council.
Accepted the final report from the Task Force on Information Literacy Competency Standards and voted to approve the Information Literacy Competency Standards for Higher Education (www. a la . org/a crl/ ilcomstan.html and see page 207).

\section{Statements}

Endorsed the Keystone Principles (CERL News, February 2000, pg. 103). In endorsing the Keystone Principles, the Board agreed to disseminate them; encourage librarians to discuss them on their campuses; and to speak about them at meetings of other organizations.

Approved the position paper "Do We Need Academic Libraries," authored by ACRL President Larry Hardesty (www.ala.org/acrl/ academiclib.html).

Endorsed "Librarianship: Core Values," a document prepared by the ALA Task Force on Core Values for the profession and suggested the addition of the following sentence at the end of the explication of "learning in all its contexts": We facilitate people becoming independent, lifelong learners. 


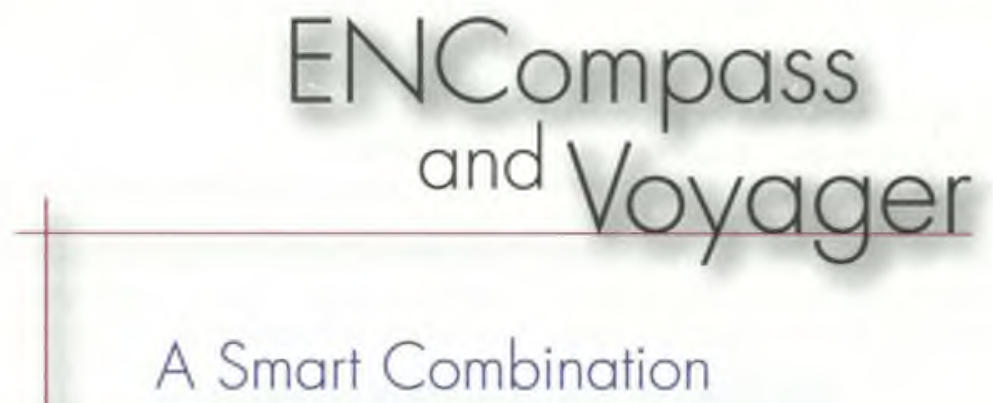

en[compass] - First, Voyager gave you inlegraled management capabilities for your library's print collection. Now Endeavor Information Systems Inc. introduces ENComposs - the nexd step in soffware for the electronic world. Crealed for loday's digital library, ENCompass takes advantage of new technology and standards (like XML, EAD, and Dublin Core) to describe, index and search a variety of electronic resources. Smartly designed to work in Iondem with Voyoger, ENCompass lets you integrate all of your resources, no matter what their location. Digital or print - now your users can have it all.

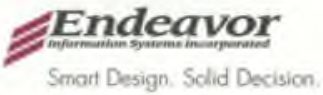

